\title{
On bricolage and the creation of sustainable postgraduate learning environments
}

\author{
S MAHLOMAHOLO
}

Abstract

In this paper I show how bricolage as a theoretical framework is used to understand and enhance the learning of the postgraduate students and academics working as a team. Bricolage is described as a metaphor for a research approach which creates something out of nothing and uses that which is available to achieve new goals. It is about finding many and new ways to resolve real life problems using that which is present in the context. It is not linear research, but research that acknowledges and works with the contradictions and incongruences in order to weave a complex text of solutions to the problems. It uses multiple voices, different textual forms and different resources, blurring neat disciplinary boundaries. In short, it splinters the dogmatism of a single approach. This theoretical positioning provides the vocabulary to describe and understand processes and interactions among the research team of $28 \mathrm{PhD}$ and 22 Masters' students being supervised by 15 academics, across the two campuses of the University of the Free State. For example, while all the actors in this team come from diverse and sometimes contradictory theoretical origins and fields of specialisation they tend to coalesce around the theme of creating sustainable learning environments in their respective research sites. To this theme they ask different questions, hence diverse aims and objectives. They also read different literature informed by the diverse groups of participants in their respective studies. Rather than being the sole determinants of their respective research agendas, they treat the participants as co-researchers who direct and inform the direction of these studies. Their methodologies acknowledge the multiple voices of those who directly experience the problem under investigation and thus can assist in the resolution thereof. They listen to all, irrespective of their station in life and, like bricoleurs, they weave meaningful solutions out of fragments of data and materials from very diverse sources of participants with different ways of doing things.

\section{Background}

In this paper I show how bricolage as the theoretical framework for a research project titled Sustainable Learning Environments ( $S u L E$ ), is used to understand and enhance the learning of the postgraduate students and academics working as a team on this project. Such a study has become urgent and necessary because research indicates that the rate of attrition not only at $\mathrm{PhD}$ level, but at all the other postgraduate qualifications, is very high both in South Africa and globally (Boshoff \& Mouton, 2008). Statistics internationally reveal that more than $65 \%$ of those who 
enrol for their $\mathrm{PhD}$ qualification never complete their studies, the same pattern occurs in as far the Master's degree is concerned (Boshoff\& Mouton, 2008; Denecke, 2005). This continues to drain the meagre resources made available by the tax paying communities. The situation, with regard to South Africa, worsens when one breaks down this percentage in terms of race, gender and social class as it ultimately becomes evident that these markers, as determinants of success, still hold the whole nation captive (National Research Foundation, 2007). Furthermore, many of those who graduate do so from a perspective that emphasises the dominant abstract knowledge, which seldom translates into practical solutions to the imminent problems in the societies (Reeves, 2011).

A bricolage is used since, to date, conventional and linear approaches to postgraduate learning have not yielded the desired levels of throughput (Boshoff \& Mouton, 2008; Denecke, 2005). Furthermore, learning thus obtained has also not proven to be sustainable beyond the acquisition of the respective qualification; hence the current poor state of education at all levels in our country as we continue to lack highly qualified leaders in education who can improve the theory and practice of education (De Beer \& Mason, 2009). It is also common knowledge that a country that does not have a significant number of $\mathrm{PhD}$ graduates is, economically speaking, not competitive because it lacks knowledge leaders who are aware of developments at the global stage and can be innovative to give the country the competitive edge (Le Grange, 2012). Le Grange is very assertive when he argues that currently we live in a space and time that requires different, multiple advanced skills - knowledge and attitudes that only a postgraduate study can provide (Le Grange, 2012).

Various strategies have been tested as a manner of addressing the problem of high levels of attrition. Some of these strategies have focused on the institution where students are enrolled following the argument that students would find it easier to move through the system if appropriate mechanisms were in place (Abiddin \& Ismail; 2011) have noted that at many institutions, facilities such as the Post Graduate Office, the Postgraduate School and so on were established, guided by this notion. A large amount of funding in many of such institutions was obtained in order to fund the postgraduate students' bursaries, research work, research material, site visits, library searches and other infrastructural resource needs (Barnes \& Randall, 2012; Department of Education - DoE, 2005; Essa, 2010). What has become apparent though is that all these efforts have not directly translated into proportionate throughput rates (Essa, 2010).

Other studies show that over and above improving the infrastructure, focus has been on capacitating the supervisors (Butler, 2009; De Beer \& Mason, 2009). Some of these have been provided with the best training possible (Butler, 2009; De Beer \& Mason, 2009; Hassad, 2010). Programmes that provide emotional, academic and professional support have been established, enabling these supervisors to execute their supervisory roles more effectively (Butler, 2009; De Beer \& Mason, 2009; Hassad, 
2010). Incentives in the form of salary increases or a once-off payment for a successful supervision of a postgraduate student have been implemented $(\mathrm{Wu}$, Griffiths, Wisker, Waller \& Illes, 2001).

Other attempts focused on the student, training him/her in all aspects of doing research (Barnes \& Randall, 2012; Butler, 2009; De Beer \& Mason, 2009; Department of Education - DoE, 2005; Essa, 2010). For example, experts would present a seminar on how to choose a research topic, how to formulate it into a proper researchtitle, how to align the literature with the aim of the study and the methodologies, how to keep the focus of the study in terms of the objectives and how to weave a coherent and logical argument from beginning to end (Barnes \& Randall, 2012; Bills, 2004; Butler, 2009; De Beer \& Mason, 2009). The students would then also be provided with the opportunity to practice the skills and knowledge provided, and feedback would almost be immediate. However, even under ideal circumstances such as these where the infrastructure was suitable, the best supervisor possible and ample opportunities for the student to learn, the success rate was still not significantly higher.

Further attempts under the banner of cohort supervision were embarked upon to broaden the interaction among the students and their peers, as well as between the students on the one hand and the supervisors as a team on the other because there was a realisation that students learned best when learning from a multiplicity of sources including other students and other supervisors (Bills, 2004; Butler, 2009; De Beer \& Mason, 2009; Mahlomaholo, 2012; 2013; 2014). This was a realisation that, because of the changing nature of the need of a postgraduate student, the days of one apprentice learning at the proverbial 'knee of the master' were gone. Currently, a post graduate student must have a wide knowledge obtained from as many sources as possible, in order to keep abreast (Mahlomaholo, 2012; 2013; 2014). The demands of a postgraduate study currently, in a complex and constantly changing world, require greater depth in terms of theoretical knowledge, methodological expertise, interpretative skills, political awareness and technological savvy, to mention a few (Kinchloe, 2004; Kinchloe \& Berry, 2008)

\section{Sustainable postgraduate learning environments}

The project reported herein, which aims at using bricolage to formulate a framework for sustainable postgraduate learning environments, is an attempt to respond to these challenges, to integrate the solutions already in place and, on the bases thereof, to create an approach far more effective in increasing throughput rates through knowledge that is functional beyond the qualification. The notion of sustainable postgraduate learning environments takes its cue from the theory of learning environments which was popularised by Eric De Corte (2000) and Barry Fraser (2002) through their mathematics and science education teams at Leuven and Curtin 
Universities respectively (Mahlomaholo, 2012; 2013; 2014). The main thrust of their argument is that for good academic performance in learning (and/or otherwise) to occur, it is not just about one's genetic make-up and inborn potentialities only, but that the context in which one lives also provides further cues for the re-creation of identity which may even include differentials in terms of performance. The theory of a learning environment thus integrates both the nature and the nurture of theoretical positions into one coherent and meaningful theory, recognising that as humans, we are born with certain potentialities that require a material context for realisation without undermining the emergent volition or agency defining who we are. De Corte (2000) and Fraser's (2002) ideas are actually an extension and further integration of both Piaget's genetic epistemology (Piaget \& Inhelder, 1973) and Vygotsky's socio-historicism (Vygotsky, 1978). This integration emphasises the interaction between the growing organism and the environment where the former depends on interiorising material objects from the latter by converting them into images and concepts for the construction of its own innate cognitive functioning. Through processes of assimilation and accommodation the growing organism opens up its pre-given cognitive scheme in order to accommodate new stimuli from the environment, which in turn contributes towards the expansion, growth and development of these innate cognitive structures through assimilation. While Piaget (Piaget \& Inhelder, 1973) above seems to be inclined towards the innate abilities, Vygotsky (1978) tends to create a balance through his emphasis on the social context which includes objects, animals, relationships, other human beings and all else as bases for the creation of ideas, thoughts, actions, identity and performance. He goes further by stating that as individuals, we can only be as good as what our context and cultural milieu allow us to be.

The integration as explained above constitutes the founding principle for almost all theories that attempt to explain and understand how academic performance is constituted. Perhaps the concept that captures the above aptly is the one developed by Teun Van Dijk (2007; 2009) and Nikita Basov (2012). Van Dijk (2007; 2009) uses the concept, 'socio-cognition' in order to describe the role of sociality in constructing innate cognitive functioning. He even introduces the notion of the epistemic community to show the immense contribution of others in our environment towards our being and our understanding, as well as to how we create meaning. It is this same concept, which Basov refers to as structural congruence, that depends on an individual's pre-given and inborn structural autonomy being influenced through interaction with and learning from other structural autonomies. Basov calls this process of two human beings mutually influencing one another structural coupling. This is a process that ultimately produces an equilibrated state of being called structural congruence where one's innate abilities are strengthened and developed through the sociality generated by others from the environment. Thus, when we talk about postgraduate learning environments, we attempt to invoke the idea and the role of the other such as sociality, context, cultural milieu, epistemic community, the 
institution, its research culture and all else which may impact on the learning processesof a postgraduate student.

Added to the concept of postgraduate learning environments is the notion of sustainability which we have appropriated from the sustainable education and sustainable development theorisations that have now found expression in the United Nations' Sustainable Development Goals (United Nations. Economic and Social Council, 2013). This concept links this study with big and broad international theories and movements which are also inspiring economic development, environmental sustainability and social inclusiion (United Nations. Economic and Social Council, 2013). These three pillars of Sustainable Development Goals (SDG) have influenced our understanding of what postgraduate learning environments are and/or should be about. Among other aspects, we also understand sustainable postgraduate learning environments as contexts where $\mathrm{PhD}$ students can learn effectively such that they meaningfully can contribute towards the economic development of the nation and beyond. $\mathrm{PhD}$ graduates are supposed to be leaders in as far as the creation of theoretical and practical knowledge is concerned, contributing directly and indirectly towards the economic development of all. Research (Centre for Research on Science and Technology \& Council for Higher Education, 2009) shows that as a nation we do not have enough people enrolled towards and completing their PhDs and this continues to impact negatively on our economy, employment levels and ability to create wealth for the wellbeing of all. On top of that, even those who are enrolled do not always complete their studies and this places a further burden on the already reeling economic base. Furthermore, the idea of sustainable postgraduate learning environments implies that a $\mathrm{PhD}$ and/or Master's study should enable our graduates to respect the environment which consists of the animals, the plants and all (United Nations. Economic and Social Council, 2013). These can and should be used for economic development but that has to be done in a responsible manner so that even future generations can still find value from them. They should not be depleted and destroyed senselessly.

The concept of sustainable postgraduate learning environments reaches a climax when it addresses the issue of social inclusivity, the third pillar of the SDG (United Nations. Economic and Social Council. 2013). This implies that a learning environment should enable the postgraduate student to contribute towards the advancement of the agenda for equity, social justice, freedom, peace and hope (Mahlomaholo, 2012a; 2012; 2013; 2014). Actually it should be the express intention of such an environment not to produce $\mathrm{PhD}$ graduates whose knowledge is so abstract that it does not have any functional practical value, especially in terms of contributing towards the democratic social transformation where all people can live together in peace and harmony. A PhD graduate should thus learn to be sensitive to discrimination of any kind and his/her role should be to use his superior learning to address and resolve that in favour of, for example, aspects such as the equitable 
distribution of resources, learning and employment opportunities,. A PhD graduate possessing these qualities will be fair and will ensure that all people are treated fairly irrespective of their origin or where they are stationed in life. The learning environment should thus enable the graduate to strive towards just and respectful relationships. It is also our understanding that a sustainable postgraduate learning environment enabling $\mathrm{PhD}$ graduates to function in the manner described above, will contribute towards the enhancement of the notion of freedom for all, as well as protecting our democracy, which will be free of strife and full of peaceful coexistence. In the case of the marginalised, we understand that sustainable postgraduate learning environments are engendering feelings of hope and confidence that the future will become a better place through knowledge and practice based on the above-mentioned principles.

\section{Bricolage towards sustainable postgraduate learning environments}

In order to create the above-mentioned learning environments we found bricolage to be the most useful theoretical framework and approach to couch our studies. Bricolage is understood to be a metaphor for research that creates "something out of nothing and uses that which is available to achieve new goals" (Aagard, 2009; Kabi, 2013; Kinchloe, 2008; Kinchloe \& Berry, 2004; Meko, 2013; Tlali, 2013; Tsotetsi, 2013). Bricolage is research that uses the materials that are available in the contexts to create and recreate new meanings (Steinberg, 2011; Wibberley, 2012). For example, the research problems, topics, aims and objectives that bricolage researchers work with are generated by the local participants as the understanding is that the people who have the problems are the very same people who have the solutions. The role of bricolage as research is to enable these people to discover the power they possess and to realise that the solutions to the problems are local. This places the responsibility of creating solutions on their shoulders as no outsider will have better expertise and knowledge than those forming part of the community concerned. The creation of sustainable postgraduate learning environments thus depends on the students, teachers and parents themselves participating practically as researchers in improving, for example, learning at their local schools.

Bricolage does not search for new tools and does not have a simplistic and linear plan of doing research from one point to the next (Kabi, 2013; Meko, 2013; Steinberg, 2011; Tlali 2013; Tsotetsi, 2013; Wibberley, 2012). It is contingent and emergent, depending on that which is available in the context. Furthermore, bricolage as a French word in knowledge and production has its origin as a metaphor used by Levi-Strauss (1966) in his structuralist pursuit to describe how primitive human beings came to know and understand the world they live in. According to him, these primitive human beings did not have access to scientific tools to enable them to acquire knowledge (Levi-Strauss, 1966) but they pieced together their own tacit knowledge with personal stories to produce a way of knowing that enabled them to understand the world they lived in. That mode of knowing may have included what 
others could have described as myths, legends and superstitions, but in the end that enabled them to bring order into their universe. Bricolage thus is about finding new and many ways to resolve real life problems using that which is in the context (Kabi, 2013; Levi -Strauss, 1966; Meko, 2013; Rogers, 2012; Steinberg, 2011; Tlali, 2013; Tsotetsi, 2013; Wibberley, 2012). It is not linear research, but research that acknowledges and works with the contradictions, complexities and incongruences in order to weave a complex text of solutions to the problems (Aagard, 2009; Kinchloe, 2008; Kinchloe \& Berry, 2004). It uses multiple voices, different textual forms and different resources (Rogers, 2012; Steinberg, 2011; Wibberley, 2012). It blurs neat disciplinary boundaries by splintering the dogmatism of a single approach (Aagard, 2009; Kinchloe, 2008; Kinchloe \& Berry, 2004; Levi -Strauss, 1966).

This theory affirms the multiplicity of voices in research thus deconstructing the monolithic view of the dominant and mainstream approach where the voices and interests of the poor and marginalised would be obviously excluded in favour of the more powerful (Denzin \& Lincoln, 2011; Kabi, 2013; Kinchloe, 2008; Meko, 2013; Tlali, 2013; Tsotetsi, 2013). For example, mainstream research had taught us about the researcher who alone formulated the research problem based on his/her academic knowledge. Such a researcher would even search for the literature including deciding on the appropriate theoretical framework to adopt for the study alone. She/he would even decide on the strategies to use in order to analyse and interpret the data in the same manner. To the contrary, bricolage preaches that the researcher has to broaden his/her area of operation by including other researchers and participants in identifying and formulating the problem for investigation, especially where research is about them (Denzin \& Lincoln, 2011; Kabi, 2013; Kinchloe, 2008; Kinchloe \& Berry, 2004; Meko, 2013; Tlali, 2013; Tsotetsi, 2013). These people are not only to remain on the periphery, but they have to become full-fledged co-researchers who even determine the whole agenda for research as well as the literature to review and theoretical framework to adopt. In fact, at every stage of the research process the researcher has to be with as many people as possible because it is that multiplicity of voices that ensures a better interpretation of the situation in a communicative action approach (Denzin \& Lincoln, 2011; Kinchloe, 2008; Kinchloe \& Berry, 2004).

The participation of many people as other co-researchers, co-supervisors of research and participants, ensures not only a diversity of voices in determining the area to be investigated but ensures that many theoretical positions are included in the study(Kabi, 2013; Meko, 2013; Rogers, 2012; Steinberg, 2011; Tlali, 2013; Tsotetsi, 2013; Wibberley, 2012). Bricolage thrives on diverse, divergent and a multiplicity of theories which are sometimes at variance with one another, but which have to be synchronised through conversations and discussions into a more integrated theoretical position affirming diversity but also being coherent (Aagard, 2009; Kabi, 2013; Kinchloe, 2008; Kinchloe \& Berry, 2004; Levi -Strauss, 1966; Meko, 2013; 
Rogers, 2012; Tsotetsi, 2013). Bricolage represents the climaxing of the historical development in qualitative research which has gone through the eight significant moments, from: traditional qualitative research, the golden age, blurred genres, crisis of representation, postmodernity, post-experimentalism, methodologically contested representation and the current fractured futures (Denzin \& Lincoln, 2011; Kinchloe, 2008; Kinchloe \& Berry, 2004).

Guided by a diversity of theoretical positions and participants in its explanatory arsenal, bricolage brings together different sources of data in the form of field notes, minutes from strategic planning sessions, meetings, observations and reflective journals to mention but a few (Levi -Strauss, 1966; Kabi, 2013; Meko, 2013; Rogers, 2012; Steinberg, 2011; Tlali, 2013; Tsotetsi, 2013; Wibberley, 2012). The methodologies used are also not one-dimensional but reflect a richness of approaches to research to provide as many perspectives as possible.

We chose and adopted bricolage because, within this approach, a researcher does not conduct research on his/her own as he/she very often has no knowledge of the problems from an informed perspective from the site of research. Bricolage affirms the fact that research is always collaborative and is defined by negotiation and communicative spaces among researchers and participants (Aagard, 2009; Kabi, 2013; Kinchloe, 2008; Kinchloe \& Berry, 2004; Levi -Strauss, 1966; Meko, 2013; Rogers, 2012; Steinberg, 2011; Tlali, 2013; Tsotetsi, 2013; Wibberley, 2012). It is an approach that expands the wisdom and perspective of one researcher by involving other researchers who can contribute meaningfully towards the resolution of a given problem. Bricolage epitomises what Basov (2012) described as structural congruence, and what Van Dijk $(2007 ; 2009)$ referred to as the epistemic community in a sociocognitive approach to knowledge production. We assumed that such an approach would go a long way towards addressing the problem of high levels of attrition if $\mathrm{PhD}$ students, who are the participants in this study, were allowed to operate in that learning community of practice where they are part of a team of researchers, and where they can learn from their own supervisors, other supervisors and their peers. However, bricolage insists that even the learners, the teachers, the parents and other instances of civil society in those school communities where the individual $\mathrm{PhD}$ students were conducting research, had to be constituted into teams facilitated by the students respectively. These layered levels of teams are critical when PhD students have to learn about problem identification and formulation as these are not imposed but democratically formulated in a collaboration of researchers and participants. In their own school communities where they facilitate research they have to listen to the participants and must be able to interpret their problems from them accordingly (Kabi, 2013; Meko, 2013; Rogers, 2012; Steinberg, 2011; Tlali, 2013; Tsotetsi, 2013; Wibberley, 2012). They have to read extensively and be practically informed in preparation for such engagements because they must be able to respectfully engage in debate with the people who experience the problems first 
hand as they identify and formulate the research problem. At the same time, these students have also to convince their peers and supervisors at subsequent project meetings about the scientific and social merits of such a formulation of the research question/topic/problem. Such an approach provides multiple opportunities for learning, debating and, as such, all parties involved, irrespective of whether they are researchers or participants, taking ownership of the research process (Kabi, 2013; Levi -Strauss, 1966; Meko, 2013; Rogers, 2012; Steinberg, 2011; Tlali, 2013; Tsotetsi, 2013; Wibberley, 2012).

Once the problem has been identified, formulated and accepted by the teams, bricolage prescribes that the teams have to work out a clear, common vision that will guide all team members in terms of the literature review, the appropriate theoretical framework and the methods and methodologies to adopt for data generation and analysis (Aagard, 2009; Kabi, 2013; Kinchloe, 2008; Kinchloe \& Berry, 2004; Levi Strauss, 1966; Meko, 2013; Tlali, 2013, 2013; Tsotetsi, 2013). Another point worth mentioning is that bricolage argues that all participants and researchers have to be accorded the same status of equality throughout the research process to the extent that by the end of the study, the initial participants have graduated into coresearchers in line with the principles of equity, social justice, freedom, peace and hope (Aagard, 2009; Kabi, 2013; Kinchloe, 2008; Kinchloe \& Berry, 2004; Meko, 2013; Tlali, 2013; Tsotetsi, 2013). The word which is used to describe this process is depowerment, in other words, the researchers must consciously be aware of the immense power they have and have to continuously check against abuse of such power. They must at all times try to participate on the same level and wavelength with the participants who have to be empowered in turn. Bricolage is a humanitarian approach to research which is mounted on the principles of critical participatory democracy and transformation, among others (Aagard, 2009; Kabi, 2013; Kinchloe, 2008; Kinchloe \& Berry, 2004; Levi -Strauss, 1966; Meko, 2013; Rogers, 2012; Steinberg, 2011; Tlali, 2013; Tsotetsi, 2013; Wibberley, 2012).

This observation also refers to bricolage's epistemological stance which argues that the truth is not a single aspect (Wibberley, 2012). The truth is created in discussions among members of the research team or the epistemic community and depends on the most powerful argument collaboratively pieced together by all, and not on the status of the researchers and/or participants (Kabi, 2013; Meko, 2013; Steinberg, 2011; Tlali, 2013; Tsotetsi; Wibberley, 2012). The truth is always negotiated given the literature and the experiences concerned. This further indicates that a high number ofparticipants who are informed and have a real stake in the issue being researched will result in better achievement of this 'truth'. In other words, the truthfulness of such knowledge depends on its usefulness and is assessed in terms of the extent to which it advances the agenda for equity, social justice, freedom, peace and hope (Aagard, 2009; Kabi, 2013; Kinchloe, 2008; Kinchloe \& Berry, 2004; Levi -Strauss, 1966; Meko, 2013; Rogers, 2012; Steinberg, 2011; Tlali, 2013; Tsotetsi, 2013; Wibberley, 
2012). This also has implications for the ontological stance of bricolage. The nature of reality is not external to the perceptions of the human beings, be they researchers or participants, hence it is important that their views, voices and inputs have to inform the study from the beginning to the end. The possibility of multiple realities and truths challenges the $\mathrm{PhD}$ students to be knowledgeable regarding their areas of investigation. They are also encouraged, in a practical sense, to be open-minded when it comes to other people and their contributions (Kabi, 2013; Kinchloe, 2008; Kinchloe \& Berry, 2004; Levi -Strauss, 1966). They are moved out of the comfortable situation of certainty to become aware of the infinite possibilities of interpretation and understanding (Aagard, 2009; Kabi, 2013; Kinchloe, 2008; Kinchloe \& Berry, 2004; Levi -Strauss, 1966; Rogers, 2012; Steinberg, 2011; Wibberley, 2012). In order to be able to function under such circumstances, extensive reading becomes the only crutch they can hold onto, in turn better preparing them to face the challenges of a PhD study.

Once the teams have formulated the common vision, they conduct an analysis consisting of the strengths, weaknesses, opportunities and threats with regard to the vision, in order to determine existing and lacking capacity to actualise it (Kabi, 2013; Mahlomaholo, 2012; 2013; 2014; Meko, 2013; Tlali, 2013; Tsotetsi, 2013). It is on the basis of these discussions that the teams firstly identify priorities and secondly jointly formulate strategic action plans to identify the activities which have to be embarked upon in order to operationalise each and every one of the priorities. For each activity the team then have to identify responsible people who will also be afforded particular resources and tied to defined time frames, for the activities to be embarked upon. The highlight of this approach is achieved when teams are able to reflect on progress made on regular basis, say once a month, to identity areas that still have to be improved in terms of implementation, re-planning, readjustment and more (Kabi, 2013; Mahlomaholo, 2112; 2113; 2014; Meko, 2013; Tlali, 2013; Tsotetsi, 2013). When these data are being generated through meetings, planning sessions and activities it must be audio/video recorded or both, to be transcribed and analysed.

The above discussion has demonstrated that the study our team conducted was important and necessary because it created the opportunities, first; for the $\mathrm{PhD}$ students and their supervisors to learn to produce knowledge in a very practical sense based on the resolution of a real life problem (Aagard, 2009; Kabi, 2013; Kinchloe, 2008; Kinchloe \& Berry, 2004; Levi -Strauss, 1966; Meko, 2013; Rogers, 2012; Steinberg, Tlali, 2013; Tsotetsi 2013; 2011; Wibberley, 2012). Secondly, even the local school communities have had the opportunity to learn take an interest and play a practical role in the resolution of a problem that affects their children and schools directly. Furthermore, this discussion has demonstrated that learning how to produce knowledge in a practical sense can enable students and researchers to be well grounded theoretically as they have to do proper literature reviewsin order to inform the choices and debates of the teams. Because the students have to defend 
their studies at all levels there is an opportunity for them to sharpen their skills in terms of writing a literature review, methodological skills and to truly own the knowledge they have acquired.

\section{Conclusion}

Out of a total of 15 students who enrolled towards their PhD in April 2011, 5 are graduating in 2013 which is a great achievement, given the fact that the average completion rate was one student in five years. There are already 15 who are submitting their work for examination by the beginning of 2014. The academics who are in the team have also experienced heightened levels of research output as they continue to publish in accredited and peer reviewed journals and books, over and above being invited not only locally but also internationally, to do keynote presentations on the achievements of their team. Even the local schools where this research has been conducted are experiencing significant improvement in terms of learner and teacher performance. Parent communities are beginning to take more interest in their children's learning's and all are beginning to learn to be free and thus contributing towards the maintenance of the democratic ethos in our communities.

The conclusion I am bound to make given all the above is that bricolage as an approach has enabled us (the whole SuLE research team) to see and to understand that researching into human life, experiences, fears and aspirations is more complex than initially thought of. We have thus become consciously aware that the successful learning of children at school is related to a complex web of relationships in the community and the social contexts within which they and their schools, their teachers and parents occur (Kinchloe, 2008; Kinchloe \& Berry, 2004). It thus was worthwhile searching and pursuing those larger processes bringing all these instances and relationships together. Kinchloe (2008) calls these the implicate orders of reality. This search in turn enabled the researchers to be multi-perspective and multi-layered in approach and to understand both the events and their contexts. As researchers, we became more open minded and versatile. We had to read more about the context, the cultural milieu, the parents, the learners, the teachers and all the actors who became participants and co-researchers accordingly. Our success was thus based on this realisation which questioned the universalism of research approach and its findings. The local became more important as we came to relate what we know to the solution of a real local problem. The findings we made could be generalised, however, this was not the intention as we understood that construction of meaning is always context bound, and that generalisations miss this richness of the particular contexts. This made research to be meaningful, relevant and interesting to the students and the participants.

In spite of all the good outcomes described above, I must indicate that this approach is very difficult to implement as it demands that we all step out of our operational 
comfort zone and create meaningful interaction with the local communities through debate and negotiation. We were challenged in the sense that we were expected to have more knowledge with regard to literature, as well as the 'ways of doing/knowing' of the communities we interact with. In the end, although complex, it was a rewarding experience.

\section{References}

Aagard, M. 2009. Bricolage: Making Do with what is at Hand. Creative Nursing, 15 (2): 82 84.

Abiddin, N.Z. \& Ismail, A. 2011. Attrition and Completion Issues in Postgraduate Studies for Student Development. International Review of Social Sciences and Humanities, 1 (1): $15-29$.

Barnes, B.J. \& Randall, J. 2012. Doctoral Student Satisfaction: An Examination of Disciplinary, Enrollment and Institutional Differences. Research in Higher Education, 53: $47-75$.

Basov, N. 2012. Knowledge Creation in the Intellectual Networks. In Basov, N \& Nenko, O. Understanding Knowledge Creation. Intellectuals in Academic, the Public Sphere and the Arts. Amsterdam: RODOPI

Bills, D. 2004. Characteristics Associated with Research Degree Student Satisfaction, Completion and Attrition at the University of South Australia. Available at http://w3.unisa.edu.au/researchededucation/supervisors] documents/ AttritionReport.pdf

Boshoff, N. \& Mouton, J. 2008. Science Policy Indicator. Available at http://hrdreview.hsrc.ac.z

Butler, G. 2009. The Design of a Postgraduate Test of Academic Literacy: Accommodating Student and Supervisor Perceptions. Southern Africa Linguistics and Applied Language Studies, 27(3): 291 - 300.

Centre for Research on Science and Technology \& Council for Higher Education. 2009. Postgraduate Studies in South Africa. A Statistical Profile. Pretoria: Council on Higher Education.

De Beer, M. \& Mason, R.B. 2009. Using a Blended Approach to Facilitate Postgraduate Supervision. Innovations and Teaching International, 46 (2): 213 - 226.

De Corte, E. 2000. High-Powered Learning Communities: A European Perspective. Center for Instructional Psychology and Technology (CIP\&T). University of Leuven, Belgium. Keynote address presented to the First Conference of the Economic and Social Research Council's Research Programme on Teaching and Learning. Leicester, England, November 9-10, 2000. Available at http://www.tlrp.orglacadpub/Corte2000.pdf

Denecke, D. 2005. Ph.D. Completion Project, Overview and Update: Council of Graduate Schools, CGS Slimmer Workshop, Santa Fe, NM, July 13, 2005.

Denzin, N.K. \& Lincoln, Y.S. 2011. The SAGE Handbook of Qualitative Research. London: Sage Books. 
Department of Education - DoE. 2005. Student Enrolment Planning in Public Higher Education. Pretoria: Government Printers.

Essa, I. 2010. Possible Contributors to Students' non-completion of the Postgraduate Diploma at Stellenbosch University. Unpublished MPhil Dissertation submitted to University of Stellenbosch. Stellenbosch.

Fraser, B. 2002. Learning Environments Research: Yesterday Today and Tomorrow. In Goh. S.C \& Khine, M.S. (eds). Studies in Educational Learning Environments: An international Perspective. Singapore: World Scientific.

Hassad, R.A. 2010. Toward Improving the Quality of Doctoral Education: A Focus on Statistics, Research Methods and Dissertation Supervision. Proceedings of the $8^{\text {th }}$ International Conference on Teaching Statistics (ICOTS 8, July 2010). Ljubljana: Slovenia.

Kabi, S.J. 2013. A Strategic Management Framework for Collaborative Resources Sharing Between Schools for Creating Sustainable Learning Environments. An Unpublished $\mathrm{PhD}$ Thesis submitted to the University of the Free State. Bloemfontein.

Kincheloe, J.L. 2008. Knowledge and Critical Pedagogy: An Introduction. Dordrecht, London: Springer.

Kinchloe, J.L \& Berry, K. 2004. Rigour and Complexity in Educational Research: Conceptualizing the Bricolage. London: Open University Press.

Le Grange, 1. 2012. Knowledge Production in the 21st Century: Some Thoughts. South African Journal of Higher Education, 26(6): 1131-1138.

Levi-Strauss, C.1966. The Savage Mind. Chicago: University of Chicago Press.

Mahlomaholo, M.G. 2012a. Creating Sustainable Learning Environments through Socially Inclusive Research. International Multidisciplinary Workshop on Marginalization Processes.

Orebro, Sweden, April 26 - 28. Available at:

http://www.oru.se/PageFiles/56054/MAHLOMAHOLO20Creating2OSustainable20Learn ing20En vironments20through20Socially20Inclusi ve20Research. pdf.

Mahlomaholo, M.G. 2012. Academic Network and Sustainable Learning Environments. Journal of Sociology and Social Anthropology, 5: 73 - 87.

Mahlomaholo, M.G. 2013. Indigenous Research and Sustainable Learning Environments. Journal of Educational Science, 5(3): 317-322.

Mahlomaholo, M.G. 2014. Higher Education and Democracy: Analysing Communicative Action in the Creation of Sustainable Learning Environments. South African Journal of Higher Education 28 (2).

Meko, T.]. 2013. Schools as Sustainable Learning Environments: A Framework for Enhancing Parental Engagement. Unpublished $\mathrm{PhD}$ Thesis Submitted to the University of the Fee State, Bloemfontein.

National Research Foundation - NRF. 2007. Institutional Development Research Programme: Programme Framework 2007-2011. Pretoria: Government Printers. 
Piaget, J. \& Inhelder, B. 1973. Memory and Intelligence. London: Routledge and Kegan Paul.

Reeves, J. 2011. Investigating Knowledge Exchange and Creation on a Practice-Based Master's Programme. Studies in Higher Education, 36 (8): 953-967.

Rogers, M. 2012. Contextualizing Theories and Practices of Bricolage Research. The Qualitative Report, 17 (7): 1-17. Available at http://www.nova.edu/ssss/QR/QR17/rogers.pdf

Steinberg, S. 2011. Introduction to "Describing the Bricolage". In Kincheloe, J.I., Hayes, K., Steinberg, S. and K. Tobin (Eds.), Keywords in Critical Pedagogy. Rotterdam: The Netherlands Sense Publishers.

Tlali, M.F. 2013. Transformational Learning of Physical Sciences through Service Learning for Sustainability. An Unpublished PhD Thesis Submitted to the University of the Free State. Bloemfontein.

Tsotetsi. C.T. 2013. The Implementation of Professional Teacher Development Policies: A Continuing Education Perspective. An Unpublished PhD Thesis Submitted to the University of the Free State. Bloemfontein,

United Nations. Economic and Social Council. 2013, Draft Resolution Submitted by the VicePresident of the Council, Martin Sajdik (Austria). Conclusion of the Work of the Commission on Sustainable Development. Vienna: United Nations.

Van Dijk, T. A. 2007. The Study of Discourse: An introduction. In Van Dijk, T. (Ed.): Discourse Studies. London: Sage.

Van Dijk, T. A. 2009. Critical Discourse Studies. A Sociocognitive Approach. In: Ruth Wodak. Mia Meyer (Eds.): Methods of Critical Discourse Analysis. London: Sage.

Vygotsky, L.S. 1978. Mind in Society. Cambridge, MA: Harvard University Press.

Wibberley, C. 2012. Getting to Grips with Bricolage: A Personal Account. The Qualitative Report, 17 (50): 1-8, Available at http://www.nova,edu/ssss/QR!QRI7/wibberley.pdf.

Wu, S., Griffiths, S., Wisker, G., Waller, S., \& Illes, K. 2001. The Learning Experience of Postgraduate Students: Matching Methods to Aims. Innovations in Education and Teaching International. London: Taylor and Francis. 